\title{
Morphological and Physiological Responses of Seashore Paspalum and Bermudagrass to Waterlogging Stress
}

\author{
Bo Xiao \\ College of Horticulture and Gardening, Yangtze University, Jingzhou, Hubei, China \\ David Jespersen ${ }^{1}$ \\ Department of Crop and Soil Sciences, University of Georgia, Griffin, GA
}

\begin{abstract}
Additional INDEX words. Cynodon sp., Paspalum vaginatum, root morphology, turfgrass, waterlogging
Abstract. Turfgrasses have varying tolerance to waterlogging conditions. The objective of this study was to identify important root traits and physiological responses to waterlogging stress in seashore paspalum (Paspalum vaginatum) and bermudagrass (Cynodon sp.). After being exposed to waterlogging conditions for 28 days, turf quality, leaf photosynthesis, transpiration rate, stomatal conductance $\left(g_{S}\right)$, and root fresh weight were significantly decreased in bermudagrass, and root lipid peroxidation was significantly increased. However, seashore paspalum was found to be more tolerant to waterlogging conditions and changes in turf quality, photosynthesis, or lipid peroxidation were not seen. The waterlogging treatments increased specific root length (SRL), surface area, and volume and decreased root respiration and diameter to a greater extent in seashore paspalum compared with bermudagrass. Under waterlogging conditions, root aerenchyma formation was found in both seashore paspalum and bermudagrass, but to a greater extent in seashore paspalum. Both grasses exhibited significant increases in root water-soluble carbohydrate (WSC) but to a lesser extent in seashore paspalum than in bermudagrass. Shoot WSC remained unchanged in seashore paspalum but was significantly increased in bermudagrass. These results indicate greater root morphological changes such as root volume, SRL, and root porosity, as well as lower root respiration may be important contributors to waterlogging tolerance for seashore paspalum.
\end{abstract}

Turfgrasses are important groundcover plants, widely used on golf courses, sports fields, and home lawns. Turfgrasses are used for aesthetic and functional reasons, including athletic surfaces, erosion control, and infiltration of rainwater (Beard and Green, 1994). Waterlogging, which causes a shortfall in oxygen available to plant roots, is a major abiotic stress in wet areas and directly results in slow growth, poor quality, or plant death (Drew, 1997). Soil texture, with high clay contents, compaction, and poor drainage may further exacerbate waterlogging conditions (Manik et al., 2019). Turfgrasses with greater waterlogging tolerance will be better able to survive these conditions, and allow turf areas to return to active use after the flooding has subsided. Understanding turfgrass responses to waterlogging is needed to identify adaptive traits related to waterlogging tolerance.

To relieve tissue anoxia under waterlogging conditions, most flood-tolerant species are capable of developing root aerenchyma, which act as channels for gas exchange between shoots and roots under hypoxic or anoxic conditions (Blom et al., 1990; Justin and Armstrong, 1987). Previous studies showed that increased waterlogging tolerance was associated with an increase in aerenchyma (Bailey-Serres and Voesenek, 2008; Justin and Armstrong, 1987; Yin et al., 2010). In saturated soils, aerenchyma formation was observed in roots of tall fescue [Lolium arundinaceum ( $\mathrm{Li}$ et al., 2001)] and creeping bentgrass [Agrostis stolonifera (Jiang and Wang, 2006)]. Aboveground changes caused by waterlogging vary

Received for publication 7 May 2019. Accepted for publication 2 July 2019. Funding was provided by the University of Georgia Research Foundation. We appreciate technical assistance provided by Krishna Katuwal.

${ }^{1}$ Corresponding author. E-mail: djesper@uga.edu. with grass species and genotype. Liu et al. (2017) reported that after 4 weeks of waterlogging, leaf number and plant height were reduced both in tall fescue and roughstalk bluegrass [Poa trivialis (Liu et al., 2017)]. However, Zhang et al. (2013) reported that the waterlogging treatment significantly increased shoot dry weight in tall fescue and kentucky bluegrass (Poa pratensis). Cardoso et al. (2013) investigated 12 Brachiaria humidicola germplasm accessions and found that some accessions increased their shoot dry mass, whereas others showed a reduction of shoot dry mass under waterlogged conditions. In contrast to shoots, relatively little is known about root changes in turfgrasses under waterlogging.

In addition to anatomical and morphological changes, waterlogging often affects metabolic processes of turfgrasses. Waterlogging promotes the production of reactive oxygen species (ROS) and the ability of turfgrasses to activate antioxidant enzymes, primarily superoxide dismutase (SOD), ascorbate peroxidase (APX), and catalase (CAT), to prevent oxidative damage has been associated with improved waterlogging tolerance (Wang and Jiang, 2007a). Due to oxygen deficiency in the plant rhizosphere, anaerobic metabolism plays an important role in producing energy for waterlogged plants, especially the activity of fermentation enzymes, including alcoholic dehydrogenase (ADH), pyruvate decarboxylase (PDC), and lactate dehydrogense (LDH) (Wang et al., 2009; Zhou et al., 2012). Waterlogging also influences carbohydrate content. Increased shoot WSC and decreased root WSC were found in waterlogged creeping bentgrass (Jiang and Wang, 2006). In kentucky bluegrass, root WSC was highly correlated with root dry weight $(\mathrm{r}=0.74)$ under waterlogging (Wang and Jiang, 2007b), suggesting that higher root WSC may contribute to better waterlogging tolerance. Photosynthesis and respiration 
are regarded as major components of waterlogging tolerance due to the need to balance the consumption of energy stores during waterlogging (Waring and Maricle, 2012). However, the photosynthetic and respiratory adaptions, along with the role of carbohydrate metabolism in turfgrass tolerance to waterlogging, are not well documented.

Of the warm-season turfgrass species commonly grown in the United States, seashore paspalum has been reported to be tolerant to flooding and low oxygen conditions (Duncan and Carrow, 2000). However, relatively little research has been performed to show how this species compares to more common turfgrasses such as bermudagrass. How the physiological mechanisms responsible for the differences in waterlogging tolerance vary between these species is yet to be determined. We hypothesized that improved waterlogging tolerance in seashore paspalum would be associated with maintenance of carbohydrate metabolism and morphological changes, such as the development of aerenchyma. The objectives for these experiments was to determine differences in waterlogging tolerance between seashore paspalum and bermudagrass, as well as to understand the physiological mechanisms responsible for differences in waterlogging tolerance found between seashore paspalum and bermudagrass.

\section{Material and Methods}

Plant materials and growing conditions. Plugs of 'Seastar' seashore paspalum and 'Tifway' bermudagrass (10 $\mathrm{cm}$ diameter) were planted into PVC containers $(50 \mathrm{~cm}$ depth, $10 \mathrm{~cm}$ diameter) containing a fritted clay material (Profile Products, Buffalo Grove, IL) and maintained in a greenhouse at the University of Georgia Griffin campus for 8 weeks to allow plants to become established. Each variety was planted in 10 containers, watered every other day, supplied weekly with 24N-3.5P-13.3K water-soluble fertilizer (Miracle-Gro; Scotts, Marysville, $\mathrm{OH}$ ), and cut twice per week to $7 \mathrm{~cm}$. On $16 \mathrm{Sept}$. 2018, the grasses were transferred to a growth chamber (Conviron, Winnipeg, MB, Canada) set to $28 / 15^{\circ} \mathrm{C}$ day/night temperatures, with a $14-\mathrm{h}$ photoperiod of $600 \mu \mathrm{mol} \cdot \mathrm{m}^{-2} \cdot \mathrm{s}^{-1}$ light. Plants were allowed to acclimate to chamber conditions for $10 \mathrm{~d}$ before stress treatments were imposed. Trimming was stopped at the beginning of waterlogging treatments.

Waterlogging treatment. Treatments started on 26 Sept. 2018 and ended on 24 Oct. 2018. Waterlogging treatment was imposed by sealing the bottom of pots with a rubber gasket, and water was added to the containers until the water level was at the soil surface of each pot. The level of water in waterlogging treatments was maintained by adding water every day. The control pots were not sealed and were well drained. These pots received normal watering every other day.

Measurements. Weekly measurements were taken to assess overall plant health and performance, including plant height, visual quality ratings, photosynthesis, and respiration. Plant height in each pot was recorded to quantify growth by average canopy height in the center of the pot. Turf quality was visually rated based on color, uniformity, and density on a scale of 1 (brown dead leaves) to 9 (turgid, green leaves) (Krans and Morris, 2007). Leaf photosynthesis and respiration measurements were made with a photosynthesis system (CIRAS-3; PP Systems, Amesbury, MA), equipped with a leaf cuvette $(18 \times$ $25 \mathrm{~mm}$ PLC3, PP Systems). Light was provided by a lightemitting diode array. Photosynthetic active radiation was set on
600 or $0 \mu \mathrm{mol} \cdot \mathrm{m}^{-2} \cdot \mathrm{s}^{-1}$ for photosynthesis and respiration measurements, respectively.

At the end of 4 weeks of treatment, turfgrasses were removed from their respective containers. The leaves were harvested, and roots were washed free of soil. A portion of the shoots and roots were immediately frozen in liquid nitrogen and stored at $-80{ }^{\circ} \mathrm{C}$ until further use. Remaining shoots and root tissue were used for morphological and physiological analysis and dried in a $70{ }^{\circ} \mathrm{C}$ oven for dry weight determination.

Root respiration measurements were made by measuring $\mathrm{CO}_{2}$ emission with modified respiration chamber, which was connected to the portable photosynthesis system operating as a closed system. Excised root tissues were sealed in the chamber, and $\mathrm{CO}_{2}$ production was quantified over time. Root samples were then oven-dried at $70{ }^{\circ} \mathrm{C}$ for $60 \mathrm{~h}$ and weighed. Root respiration was calculated as micromoles of $\mathrm{CO}_{2}$ per second per gram dry weight.

Root samples were then scanned with a flatbed scanner, and the images were analyzed using the GiA Roots software (Galkovskyi et al., 2012). Root morphological traits, including root volume (cubic millimeters), surface area (square millimeters), length (millimeters), and mean diameter (millimeters) of root samples were determined via software analysis. After measuring the morphological traits, all root segments were dried at $70^{\circ} \mathrm{C}$ for $60 \mathrm{~h}$ and weighed. Root volume, surface area, root specific volume (root volume per unit dry mass) and SRL (length per unit dry mass of the samples) were calculated. The relative amount of aerenchyma in the root cortex was assessed by root specific volume, with greater aerenchymal associated air spaces increasing specific volume. Root aerenchyma formation was further analyzed by making freehand sections at 10 $\mathrm{cm}$ behind the root tip; four roots per replicate were examined. The sections were then observed under a microscope for the presence or absence of aerenchyma.

The WSC was measured using the anthrone method (Koehler, 1952), with some modifications. Approximately $50 \mathrm{mg}$ dry root or dry leaf tissues were cut into $0.5-\mathrm{cm}$ segments. The WSC was extracted with $10 \mathrm{~mL}$ double distilled water in a boiling water bath for $5 \mathrm{~h}$, then centrifuged at $15,000 \mathrm{~g}_{\mathrm{n}}$ for $10 \mathrm{~min}$ and the supernatant was collected. The extraction was repeated two times and the supernatant was pooled. A $0.5-\mathrm{mL}$ aliquot of extract and $1.5 \mathrm{~mL}$ double distilled water was mixed with $5 \mathrm{~mL}$ freshly prepared anthrone reagent $[200 \mathrm{mg}$ anthrone, $100 \mathrm{~mL}$ $95 \%(\mathrm{w} / \mathrm{w}) \mathrm{H}_{2} \mathrm{SO}_{4}$ ] and placed in a boiling water bath for $5 \mathrm{~min}$. After cooling, the absorbance at $630 \mathrm{~nm}$ was read. The standard curve was made using glucose using a range of 5 to $200 \mu \mathrm{g} \cdot \mathrm{mL}^{-1}$.

Lipid peroxidation was estimated by measuring malondialdehyde (MDA) content based on the methods of Hodges et al. (1999), with some modifications. Fresh root tissues $(100 \mathrm{mg})$ were ground into fine powder using liquid nitrogen and were put into 80:20 (v:v) ethanol:water, followed by centrifugation at $10,000 g_{\mathrm{n}}$ for $10 \mathrm{~min}$. Then $0.5 \mathrm{~mL}$ supernatant was mixed with $0.5 \mathrm{~mL}$ of $20 \%$ trichloroacetic acid containing $0.65 \%$ thiobarbituric acid. The mixture was heated at $95{ }^{\circ} \mathrm{C}$ for $30 \mathrm{~min}$, quickly cooled, and then centrifuged at $15,000 \mathrm{~g}_{\mathrm{n}}$ for $10 \mathrm{~min}$. The absorbance was read at 450, 532, and $600 \mathrm{~nm}$. The MDA concentration can be estimated through the following formula: $($ micromoles per liter $)=6.45(\mathrm{~A} 532-\mathrm{A} 600)-0.56 \cdot \mathrm{A} 450(\mathrm{Ye}$ et al., 2015).

Root viability was determined using the reduction of 2,3,5triphenyl tetrazolium chloride [TTC (Gondor et al., 2013)]. 
Root samples $(50 \mathrm{mg})$ near the midpoint of roots harvested at the end of the experiment were put into $10-\mathrm{mL}$ vials containing $3 \mathrm{~mL} 0.6 \%$ TTC in $50 \mathrm{~mm}$ phosphate buffer (pH 7.5) and then incubated at room temperature in the dark for $24 \mathrm{~h}$. The formazan generated was extracted with $5 \mathrm{~mL}$ ethanol at $60{ }^{\circ} \mathrm{C}$ for $30 \mathrm{~min}$. The absorbance was read at $485 \mathrm{~nm}$, and root viability was calculated as A485 per gram dry weight.

Data ANALYSIS. The experiment was arranged in a completely randomized design, totaling 20 pots with five replicates for the control and waterlogging treatments for each species. Pots were rotated within the chamber weekly to avoid potential localized environmental variations. Normality of data were tested using the Shapiro-Wilk Test. Data were analyzed using an analysis of variance in SAS (version 9.1; SAS Institute, Cary, NC), when significant Fisher's protected least significant difference was used for means separation.

\section{Results and Discussion}

EFFECTS OF WATERLOGGING ON SHOT FRESH WEIGHT, ROOT FRESH WEIGHT, PLANT HEIGHT, AND TURFGRASS QUALITY. Over the $28 \mathrm{~d}$ of treatment, bermudagrass saw a significant decline in overall visual quality in the waterlogging treatment due to a higher number of senescent yellow leaves, with ratings declining from 8.6 in control conditions down to 6.8 in the waterlogging treatment (Figs. 1A). There were no significant changes in seashore paspalum visual quality for the 28-d treatment duration (Fig. 1A). However, waterlogging treatments did not have any significant effects on shoot height or biomass in either seashore paspalum or bermudagrass (Fig. 1CD).

Waterlogging stress did not significantly alter root fresh weight in seashore paspalum, but significantly decreased root fresh weight in bermudagrass, compared with the control treatment (Fig. 1B). Under waterlogging conditions, root fresh weight was $6 \%$ and $62 \%$ lower than under the non-waterlogging treatment for seashore paspalum and bermudagrass, respectively.

Differences in overall visual quality and root biomass demonstrate that waterlogging tolerance of seashore paspalum is greater than bermudagrass, which is in agreement with previous claims. Barrett-Lennard et al. (2003) classified seashore paspalum as high tolerant to waterlogging, whereas Duncan and Carrow (2000) reported bermudagrass as being sensitive. However, Zong et al. (2015) reported that seashore paspalum showed reductions in biomass under $30 \mathrm{~d}$ of waterlogging and was regarded as an intolerant grass compared with knotgrass (Paspalum paspaloides) and spiny mudgrass (Pseudoraphis spinescens). The specific variety being tested and environmental conditions may also influence results. It was
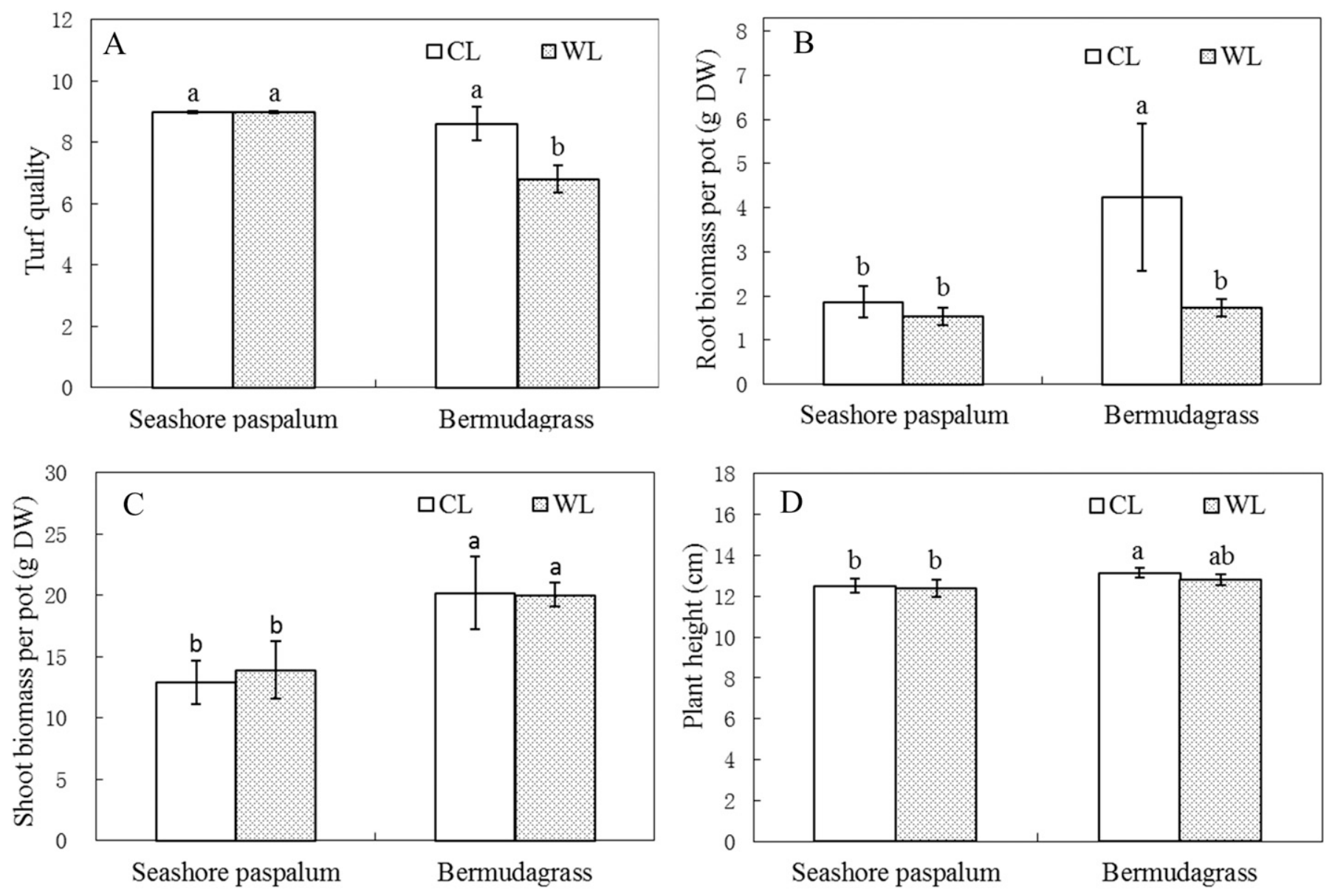

Fig. 1. Turf quality ratings based on a 1 to 9 scale with 9 being turgid, green leaves and 1 being completely dead (A), root biomass (B), shoot biomass (C), and plant height (D) of seashore paspalum and bermudagrass grown under control (CL) or waterlogged (WL) soil conditions for $28 \mathrm{~d}$. Error bars indicate SD ( $\mathrm{n}=5$ ), and letters represent least significant difference groups at $P \leq 0.05$. 
previously reported that among eight seashore paspalum genotypes there were differences in tolerance to anoxia (Pompeiano et al., 2017). Tan et al. (2010) reported that bermudagrass can endure long-term and deep submergence. However, their experiment was carried out in winter and may indicate that bermudagrass has a high tolerance to submergence during dormancy.

Waterlogging can influence the overall growth performance in many grass species (Beloni et al., 2017; Hare et al., 2004; Huang et al., 1998; Li et al., 2018; Wang et al., 2009; Ye et al., 2003; Zong et al., 2015). Generally, waterlogging decreases plant growth. However, elongation of stems and leaves and increased biomass were also observed in flood-tolerant plants under flooding (Blom and Voesenek, 1996; Insausti et al., 1999; Laan and Blom, 1990). Regardless of specific changes in growth due to waterlogging effects, biomass is regarded as a major factor to evaluate waterlogging tolerance. In our study, waterlogging significantly reduced root biomass, although it did not affect shoot biomass in bermudagrass. It appears that root tissues are more sensitive than shoots to waterlogging in turfgrasses due to hypoxic conditions, and rapid root adaptation to waterlogging may be an important tolerance mechanism.

EFFECTS OF WATERLOGGING ON ROOT MORPHOLOGY AND AERENCHYMA FORMATION. Compared with the control treatment, the waterlogging treatment significantly decreased root diameter in seashore paspalum and bermudagrass by $29 \%$ and $18 \%$, respectively. However, seashore paspalum had signifi- cantly greater average root diameter than bermudagrass under both control and waterlogging treatments (Fig. 2A). Specific root length was significantly increased by $309 \%$ and $145 \%$, respectively, in seashore paspalum and bermudagrass exposed to waterlogging compared with control treatments (Fig. 2B). Root surface area per pot in seashore paspalum was increased significantly under waterlogging condition (Fig. 2C). However, waterlogging treatment significantly decreased root surface area per pot in bermudagrass.

Under waterlogging conditions, root aerenchyma formation was found in both seashore paspalum and bermudagrass based on root cross-section observations (Fig. 3). Extensive aerenchyma formation is further supported by the fact that root volume per unit dry mass increased in both species indicating a greater proportion of airspaces and porosity in root tissues (Fig. 2D). However, the development of aerenchyma was significantly greater in waterlogged seashore paspalum than bermudagrass with greater porosity seen in waterlogged seashore paspalum than in bermudagrass. Our study is consistent with the results of Liu et al. (2017), who reported that the increase of aerenchyma in waterlogged roughstalk bluegrass was greater than in waterlogged tall fescue and was one of the characteristics most likely to contribute to better waterlogging tolerance in roughstalk bluegrass. Increased aerenchyma formation was also observed in flooding-tolerant Paspalum dilatatum (Insausti et al., 2001), and waterlogged Dendranthema species (Yin et al., 2010).
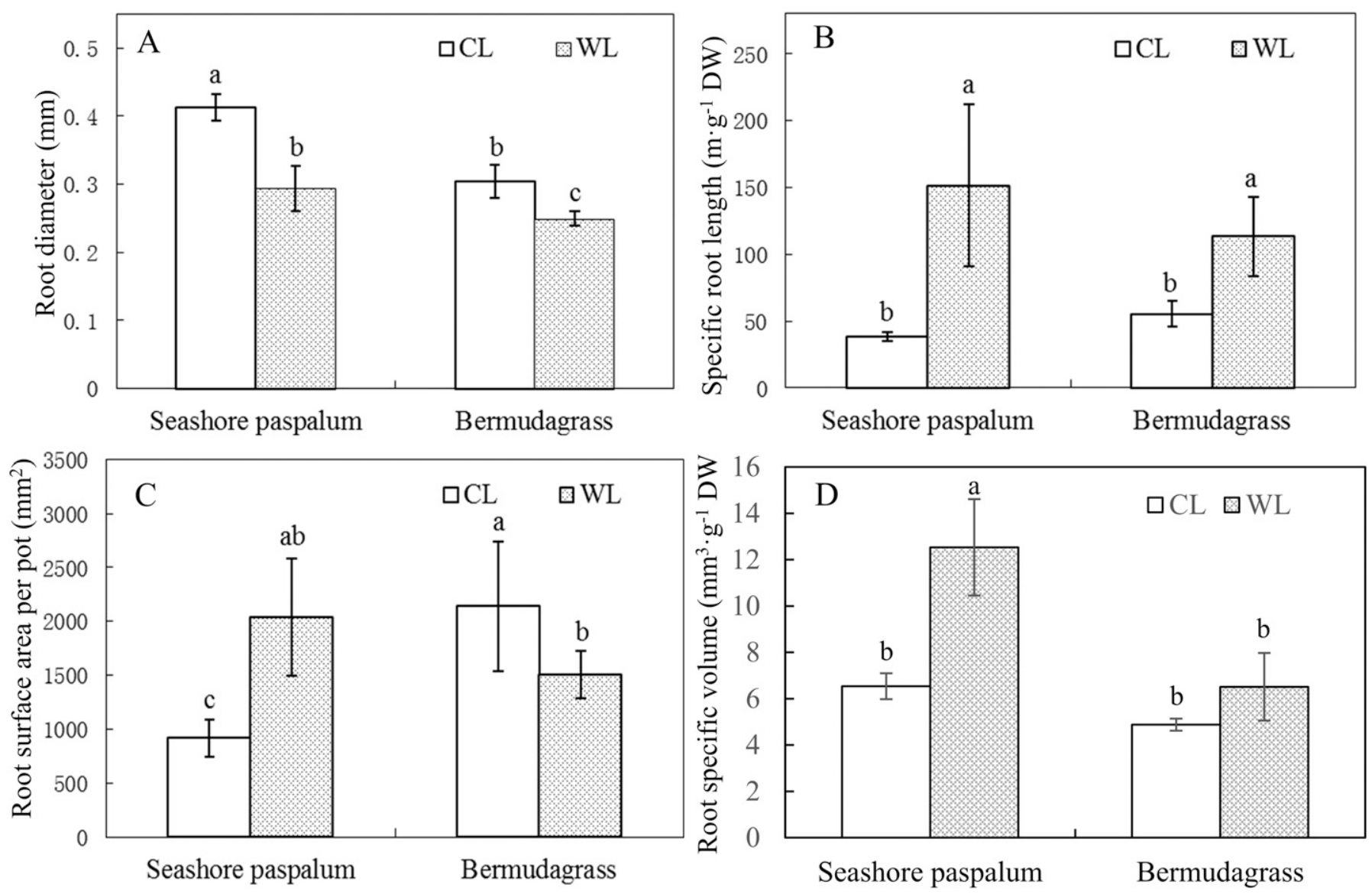

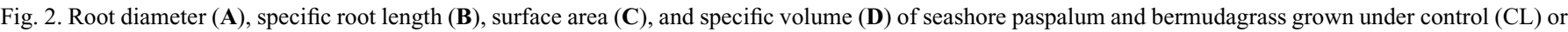
waterlogged $(\mathrm{WL})$ soil conditions for $28 \mathrm{~d}$. Error bars indicate sD $(\mathrm{n}=5)$, and letters represent least significant difference groups at $P \leq 0.05$. 


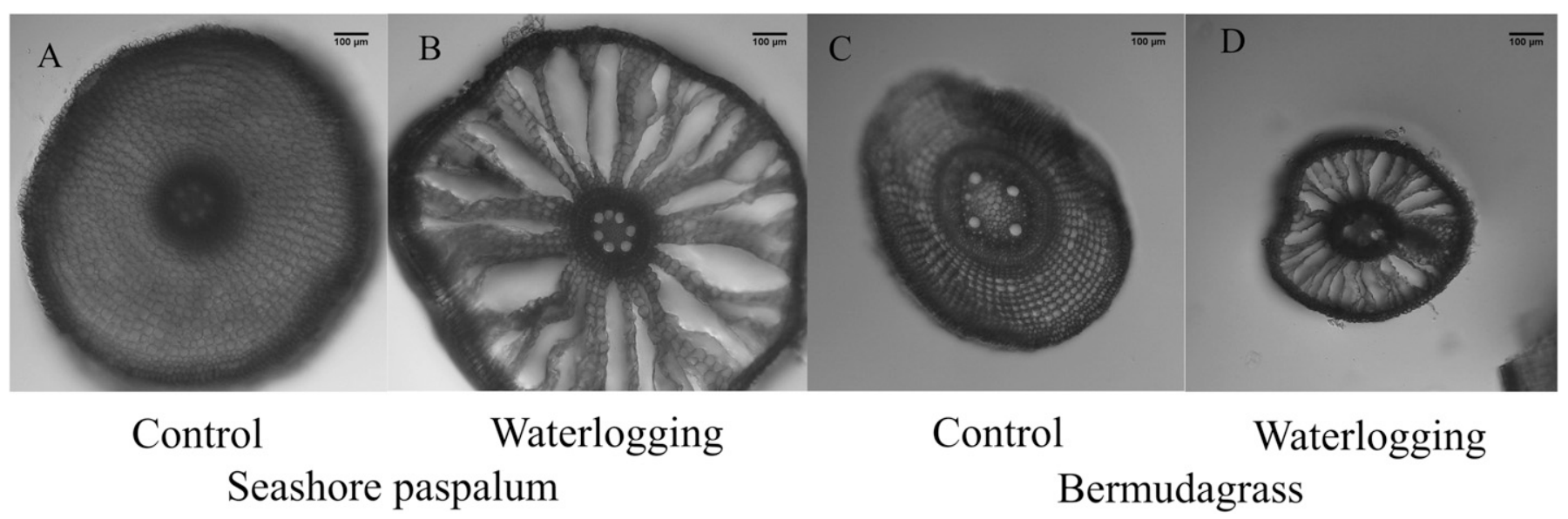

Fig. 3. Representative image of transverse root sections of seashore paspalum and bermudagrass in control and waterlogging treatments.

Root diameter is also associated with waterlogging tolerance. Liu et al., (2017) reported that the root diameter of roughstalk bluegrass was less than tall fescue, and roughstalk bluegrass had more total roots than tall fescue. Root systems with smaller diameters have greater surface-area to volume ratios (Lamont, 1983). Root systems with larger surface-area to volume ratios usually have greater nutrient absorption efficiency and gas diffusion rates under normal non-water-logged conditions (Guo et al., 2016). The current results indicate that bermudagrass, with its smaller root diameters, had less waterlogging tolerance compared with seashore paspalum. Under well-drained conditions, a finer root may be advantageous, but the larger root diameter in seashore paspalum may allow for rapid and more extensive aerenchyma development, resulting in improved waterlogging tolerance. Both grasses had a decrease in root diameter, and in turn greater specific root length, under waterlogging treatment. However, seashore paspalum's ability to maintain root biomass resulted in significantly greater surface area. Increased fine lateral roots and SRL have been found to increase under waterlogging in flooding-tolerant $\mathrm{C} 4$ grasses and have been proposed to be an adaptive trait to improve nutrient uptake under waterlogged conditions (Cardoso et al., 2014; Rubio et al., 1997). Due to changes in root morphology and a similar root dry weight between waterlogged and control conditions, waterlogged seashore paspalum had greater total root surface area and total root volume than controls. Although waterlogged bermudagrass had significant increases in root surface area and root volume per unit root dry weight, total root surface area and total root volume under waterlogging decreased because of the reduction in total root dry weight.

EFFECTS OF WATERLOGGING ON LEAF PHOTOSYNTHESIS, RESPIRATION, AND ROOT RESPIRATION. Compared with the control treatment, the waterlogging treatment did not significantly affect leaf photosynthesis, transpiration rate, $g_{\mathrm{S}}$, and internal $\mathrm{CO}_{2}$ concentration in seashore paspalum (Fig. 4A-D). However, waterlogging significantly decreased leaf photosynthesis, transpiration rate, and $g_{\mathrm{S}}$ in bermudagrass by $26 \%, 30 \%$, and $33 \%$, respectively at $28 \mathrm{~d}$ of waterlogging, whereas internal $\mathrm{CO}_{2}$ concentration remained unchanged (Fig. 4A-D). Under waterlogging conditions, leaf respiration significantly increased in bermudagrass but was not significantly affected in seashore paspalum (Fig. 4E). The maintenance of photosyn- thesis in seashore paspalum provides further evidence of improved waterlogging tolerance compared with bermudagrass. Reduced photosynthesis has been reported in many dryland species under waterlogging (Ahmed et al., 2002; Liu et al., 2017; Naidoo and Mundree, 1993). Rapid declines in $g_{\mathrm{S}}$ were observed in several plant species under flooded conditions (Else et al., 1995), and stomata closure is considered to be a major reason for reduced photosynthesis during flooding (Pezeshki et al., 1996). However, photosynthesis reduction has also been found when $g_{\mathrm{S}}$ does not decline during the early waterlogging periods (Ahmed et al., 2002). Many studies suggested that chlorophyll content reduction may result in reduced photosynthetic capacity during long-term waterlogging stress (Close and Davidson, 2003; Jiménez et al., 2015; Ou et al., 2011), and waterlogging treatment can affect chlorophyll content differently in grass species (Ashraf and Yasmin, 1991; Jiang and Wang, 2006). In our study, the reduced photosynthesis in bermudagrass may be associated with declines in photosynthetic pigments or reduced $g_{\mathrm{S}}$ given that both were observed.

In addition to photosynthetic differences, seashore paspalum and bermudagrass differed in root respiration in response to waterlogging. Root respiration $\left(\mathrm{CO}_{2}\right.$ production) in seashore paspalum and bermudagrass exposed to waterlogging significantly decreased by $68 \%$ and $43 \%$, respectively (Fig. 4F). Our results indicated that root metabolism was more sensitive to waterlogging than leaf metabolism. Similar results were reported by Liu et al. (2017). Plant tolerance to waterlogginginduced hypoxia appeared to be associated with low root respiration in wheat [Triticum aestivum (Huang and Johnson, 1995)]. Reduction in root respiration rates have been observed in many plants under anoxia, regardless of whether the plants are flooding tolerant or intolerant (Carpenter and Mitchell, 1980; Kuo and Chen, 1980; Lambers, 1976; Liao and Lin, 1995; Lin and Lin, 1992; Su and Su, 1996). Pompeiano et al. (2017) found that improved tolerance to anoxia in seashore paspalum may be due to reduced respiration but not necessarily sugar starvation. Given the increased reliance on anaerobic metabolism for energy during waterlogging, changes in fermentation usually represent adaptive strategies for waterlogging tolerance (Xu et al., 2014). Under similar anoxic conditions, lower fermentation activity produces fewer toxic metabolites and subsequently less damage to plant cells (Fukao and 

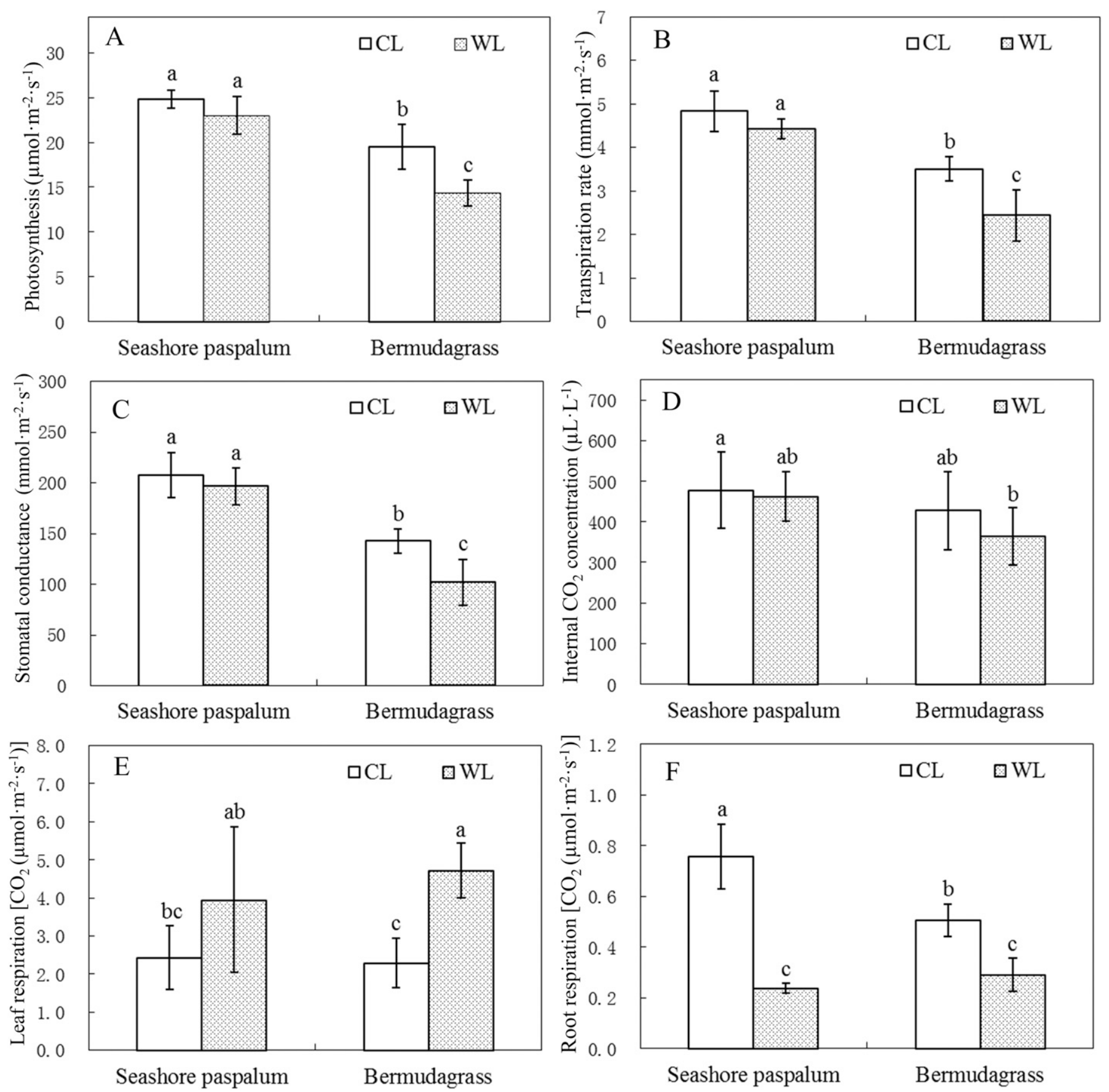

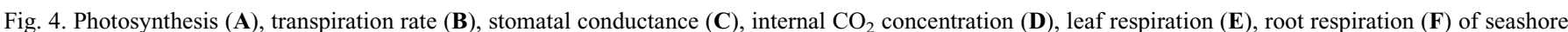
paspalum and bermudagrass grown under control $(\mathrm{CL})$ or waterlogged $(\mathrm{WL})$ soil conditions for $28 \mathrm{~d}$. Error bars indicate sD (n $=5$ ), and letters represent least significant difference groups at $P \leq 0.05$.

Bailey-Serres, 2004). In our study, a decrease in root respiration in seashore paspalum might be associated with lower fermentation rates, and therefore lower root respiration is likely a factor contributing to waterlogging tolerance in seashore paspalum.

EFFECTS OF WATERLOGGING ON ROOT WSC, ROOT MDA CONTENT, AND ROOT VIABILITY. Waterlogging treatment significantly increased root WSC in seashore paspalum and bermudagrass by $58 \%$ and $103 \%$, respectively (Fig. 5A). The waterlogging treatment did not affect shoot WSC in seashore paspalum (Fig. 5B), but there was significantly increased shoot WSC in bermudagrass, by $135 \%$, resulting in both higher root and shoot WSC in bermudagrass during waterlogging compared with seashore paspalum. Frequently, waterlogging causes a shift in plants from aerobic respiration to alcoholic fermentation. As the substrates for alcoholic fermentation, WSC is regarded as one of the relevant factors for grass species exposed to waterlogging (Liu and Jiang, 2015; Wang and Jiang, 2007b). Stored carbohydrates are reported to be associated with enhanced survival under flooding conditions (Sarkar et al., 

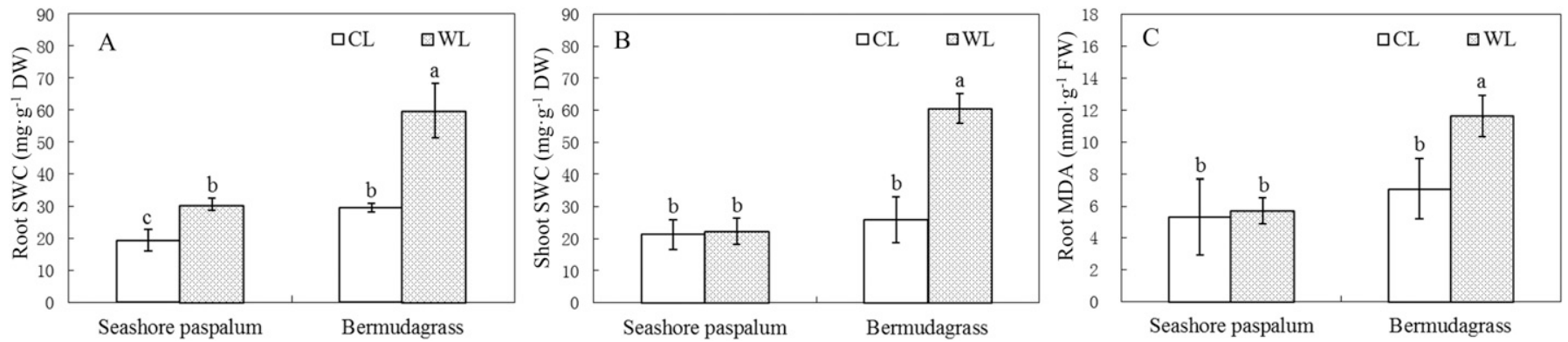

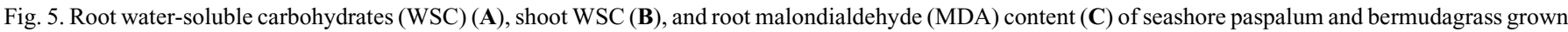
under control (CL) or waterlogged (WL) soil conditions for $28 \mathrm{~d}$. Error bars indicate SD $(\mathrm{n}=5)$, and letters represent least significant difference groups at $P \leq 0.05$.

1996; Vriezen et al., 2003). However, carbohydrate reserves do not always contribute to flood tolerance. For example, high carbohydrate reserves in japanese lawngrass (Zoysia japonica) did not determine anoxia tolerance (Pompeiano et al., 2017). A slow and well-controlled use of sugars, rather than their relative abundance, has been associated with improved anoxia tolerance (Banti et al., 2013). In our study, root WSC significantly increased in seashore paspalum and bermudagrass, indicating changes in carbohydrate metabolism during waterlogging. However, the degree of increase was not correlated with waterlogging tolerance, and greater increases in WSC were found in waterlogging-sensitive bermudagrass, perhaps indicating that a lesser ability to regulate respiration metabolism.

Lipid peroxidation estimated by MDA content was unaltered in the roots of seashore paspalum exposed to waterlogging conditions but significantly increased in bermudagrass indicating greater oxidative damage (Fig. 5C). Root viability was unaffected by waterlogging in both grasses. Waterlogging increased MDA in several species, such as kentucky bluegrass (Puyang et al., 2015) and perennial ryegrass [(Liu and Jiang, 2015; Yin et al., 2017)]. However, root MDA remained unchanged in creeping bentgrass cultivars under waterlogging conditions (Wang and Jiang, 2007a). It seems that waterlogging-induced root MDA might be species- and stressspecific. Increased MDA content is generally considered an indicator of membrane damage and lipid peroxidation. In our study, seashore paspalum appeared to have higher waterlogging tolerance than bermudagrass because under waterlogging stress, the former had a lower MDA content than the latter.

\section{Conclusions}

In summary, seashore paspalum was found to be more waterlogging tolerant than bermudagrass, with root morphology, root respiration rates, and root WSC being the most distinguishable traits associated with waterlogging tolerance between the two species. The greater development of aerenchyma in seashore paspalum may allow it to maintain greater access to oxygen and therefore maintain more normal metabolic processes. Additionally, seashore paspalum decreased its respiration rate to a greater extent than bermudagrass, which may be an important mechanism in reducing energy use under waterlogged conditions. Interestingly, despite lower respiration rates and concentrations of WSC, seashore paspalum was better able to maintain root growth during waterlogging conditions. Understanding the regulation of root metabolism during waterlogging conditions will be a key research area to improve waterlogging tolerance in turfgrasses.

\section{Literature cited}

Ahmed, S., E. Nawata, M. Hosokawa, Y. Domae, and T. Sakuratani. 2002. Alterations in photosynthesis and some antioxidant enzymatic activities of mungbean subjected to waterlogging. Plant Sci. 163:117-123.

Ashraf, M. and H. Yasmin. 1991. Differential waterlogging tolerance in three grasses of contrasting habitats: Aeluropus lagopoides (L.) Trin., Cynodon dactylon (L.) Pers. and Leptochloa fusca (L.). Kunth. Environ. Expt. Bot. 31:437-445.

Bailey-Serres, J. and L.A.C.J. Voesenek. 2008. Flooding stress: Acclimations and genetic diversity. Annu. Rev. Plant Biol. 59:313-339.

Banti, V., B. Giuntoli, S. Gonzali, E. Loreti, L. Magneschi, G. Novi, E. Paparelli, S. Parlanti, C. Pucciariello, A. Santaniello, and P. Perata. 2013. Low oxygen response mechanisms in green organisms. Intl. J. Mol. Sci. 14:4734-4761.

Barrett-Lennard, E.G., C.V. Malcolm, and A. Bathgate. 2003. Saltland pastures in Australia: A practical guide. 2nd ed. Land, Water \& Wool Sustainable Grazing on Saline Lands Sub-Program, Perth, Australia. Beard, J.B. and R.L. Green. 1994. The role of turfgrasses in environmental protection and their benefits to humans. J. Environ. Qual. 23:452-460.

Beloni, T., C.G. Pezzopane, G.A. Rovadoscki, A.P. Fávero, M.B. Dias-Filho, and P.M. Santos. 2017. Morphological and physiological responses and the recovery ability of Paspalum accessions to water deficit and waterlogging. Grass Forage Sci. 72:840-850.

Blom, C.W.P.M. and L.A.C.J. Voesenek. 1996. Flooding: The survival strategies of plants. Trends Ecol. Evol. 11:290-295.

Blom, C.W.P.M., G.M. Bögemann, P. Laan, A.J.M. van der Sman, H.M. van de Steeg, and L.A.C.J. Voesenek. 1990. Adaptations to flooding in plants from river areas. Aquat. Bot. 38:29-47.

Cardoso, J.A., J. Rincón, J.C. Jiménez, D. Noguera, and I.M. Rao. 2013. Morpho-anatomical adaptations to waterlogging by germplasm accessions in a tropical forage grass. AoB Plants 5:plt047.

Cardoso, J.A., J.C. Jiménez, and I.M. Rao. 2014. Waterlogginginduced changes in root architecture of germplasm accessions of the tropical forage grass Brachiaria humidicola. AoB Plants 6:plu017.

Carpenter, J.R. and C.A. Mitchell. 1980. Root respiration characteristics of flood-tolerant and intolerant tree species. J. Amer. Soc. Hort. Sci. 105:684-687.

Close, D.C. and N.J. Davidson. 2003. Long-term waterlogging: Nutrient, gas exchange, photochemical and pigment characteristics of Eucalyptus nitens saplings. Russ. J. Plant Physiol. 50:843-847.

Drew, M.C. 1997. Oxygen deficiency and root metabolism: Injury and acclimation under hypoxia and anoxia. Annu. Rev. Plant Physiol. Plant Mol. Biol. 48:223-250.

Duncan, R.R. and R.N. Carrow. 2000. Seashore paspalum: The environmental turfgrass. Wiley, Hoboken, NJ.

Else, M.A., W.J. Davies, M. Malone, and M.B. Jackson. 1995. A negative hydraulic message from oxygen-deficient roots of tomato plants? Influence of soil flooding on leaf water potential, leaf 
expansion, and synchrony between stomatal conductance and root hydraulic conductivity. Plant Physiol. 109:1017-1024.

Fukao, T. and J. Bailey-Serres. 2004. Plant responses to hypoxia-Is survival a balancing act? Trends Plant Sci. 9:449-456.

Galkovskyi, T., Y. Mileyko, A. Bucksch, B. Moore, O. Symonova, C.A. Price, C.N. Topp, A.S. Iyer-Pascuzzi, P.R. Zurek, S. Fang, J. Harer, P.N. Benfey, and J.S. Weitz. 2012. GiA Roots: Software for the high throughput analysis of plant root system architecture. BMC Plant Biol. 12:116.

Gondor, O.K., T. Janda, and G. Szalai. 2013. Comparative study of viability measurement methods in crop plants. Acta Agron. Hung. 61:219-226.

Guo, P., H. Jin, H. Wei, L. Li, and Y. Bao. 2016. Fine root growth and water use efficiency in alfalfa (Medicago sativa L. cv. Gongong No. 1) planted along a salinity gradient in coastal area of Dalian, northeast China. Soil Sci. Plant Nutr. 62:164-172.

Hare, M.D., M. Saengkham, P. Tatsapong, K. Wongpichet, and S. Tudsri. 2004. Waterlogging tolerance of some tropical pasture grasses. Trop. Grassl. 38:227-233.

Hodges, D.M., J.M. DeLong, C.F. Forney, and R.K. Prange. 1999. Improving the thiobarbituric acid-reactive-substances assay for estimating lipid peroxidation in plant tissues containing anthocyanin and other interfering compounds. Planta 207:604-611.

Huang, B. and J.W. Johnson. 1995. Root respiration and carbohydrate status of two wheat genotypes in response to hypoxia. Ann. Bot. 75:427-432.

Huang, B., X. Liu, and J.D. Fry. 1998. Effects of high temperature and poor soil aeration on root growth and viability of creeping bentgrass. Crop Sci. 38:1618-1622.

Insausti, P., A.A. Grimoldi, E.J. Chaneton, and V. Vasellati. 2001. Flooding induces a suite of adaptive plastic responses in the grass Paspalum dilatatum. New Phytol. 152:291-299.

Insausti, P., E.J. Chaneton, and A. Soriano. 1999. Flooding reverted grazing effects on plant community structure in mesocosms of lowland grassland. Oikos 84:266-276.

Jiang, Y.W. and K.H. Wang. 2006. Growth, physiological and anatomical responses of creeping bentgrass cultivars to different depths of waterlogging. Crop Sci. 46:2420-2426.

Jiménez, J.C., J.A. Cardoso, M. Dominguez, G. Fischer, and I. Rao. 2015. Morpho-anatomical traits of root and non-enzymatic antioxidant system of leaf tissue contribute to waterlogging tolerance in Brachiaria grasses. Grassl. Sci. 61:243-252.

Justin, S.H.F.W. and W. Armstrong. 1987. The anatomical characteristics of roots and plant response to soil flooding. New Phytol. 106:465-495.

Koehler, L.H. 1952. Differentiation of carbohydrates by anthrone reaction rate and color intensity. Anal. Chem. 24:1576-1579.

Krans, J.V. and K. Morris. 2007. Determining a profile of protocols and standards used in the visual field assessment of turfgrasses: A survey of national turfgrass evaluation program-sponsored university scientists. Appl. Turfgrass Sci. 4:1-6.

Kuo, C.G. and B.W. Chen. 1980. Physiological responses of tomato cultivars to flooding. J. Amer. Soc. Hort. Sci. 105:751-755.

Laan, P. and C.W.P.M. Blom. 1990. Growth and survival responses of Rumex species to flooded and submerged conditions: The importance of shoot elongation, underwater photosynthesis and reserve carbohydrates. J. Expt. Bot. 41:775-783.

Lambers, H. 1976. Respiration and NADH-oxidation of the roots of flood-tolerant and flood-intolerant Senecio species as affected by anaerobiosis. Physiol. Plant. 37:117-122.

Lamont, B. 1983. Root hair dimensions and surface/volume/weight ratios of roots with the aid of scanning electron microscopy. Plant Soil 74:149-152.

Li, D., L. Han, N.E. Christians, and D.D. Minner. 2001. Morphological changes of tall fescue in response to saturated soil conditions. Intl. Turfgrass Soc. Res. J. 9:317-322.

Li, S.H., Z.M. Ge, L.N. Xie, W. Chen, L. Yuan, D.Q. Wang, X.Z. Li, and L.Q. Zhang. 2018. Ecophysiological response of native and exotic salt marsh vegetation to waterlogging and salinity: Implications for the effects of sea-level rise. Sci. Rpt. 8:2441, doi: 10.1038/ s41598-017-18721-z.

Liao, C.T. and C.H. Lin. 1995. Effect of flood stress on morphology and anaerobic metabolism of Momordica charantia. Environ. Expt. Bot. 35:105-113.

Lin, C.H. and C.H. Lin. 1992. Physiological adaptation of waxapple to waterlogging. Plant Cell Environ. 15:321-328.

Liu, M., A. Hulting, and C. Mallory-Smith. 2017. Comparison of growth and physiological characteristics between roughstalk bluegrass and tall fescue in response to simulated waterlogging. PLoS One 12:e0182035.

Liu, M. and Y. Jiang. 2015. Genotypic variation in growth and metabolic responses of perennial ryegrass exposed to short-term waterlogging and submergence stress. Plant Physiol. Biochem. 95:57-64.

Manik, S.M.N., G. Pengilley, G. Dean, B. Field, S. Shabala, and M. Zhou. 2019. Soil and crop management practices to minimize the impact of waterlogging on crop productivity. Front. Plant Sci. 10:140.

Naidoo, G. and S.G. Mundree. 1993. Relationship between morphological and physiological responses to waterlogging and salinity in Sporobolus virginicus (L.) Kunth. Oecologia 93:360-366.

Ou, L.J., X.Z. Dai, Z.Q. Zhang, and X.X. Zou. 2011. Responses of pepper to waterlogging stress. Photosynthetica 49:339-345.

Pezeshki, S.R., J.H. Pardue, and R.D. DeLaune. 1996. Leaf gas exchange and growth of flood-tolerant and flood-sensitive tree species under low soil redox conditions. Tree Physiol. 16:453458.

Pompeiano, A., T. Huarancca Reyes, T.M. Moles, M. Villani, M. Volterrani, L. Guglielminetti, and A. Scartazza. 2017. Inter- and intraspecific variability in physiological traits and post-anoxia recovery of photosynthetic efficiency in grasses under oxygen deprivation. Physiol. Plant. 161:385-399.

Puyang, X., M. An, L. Xu, L. Han, and X. Zhang. 2015. Antioxidant responses to waterlogging sress and subsequent recovery in two kentucky bluegrass cultivars. Acta Physiol. Plant. 37:197.

Rubio, G., M. Oesterheld, C.R. Alvarez, and R.S. Lavado. 1997. Mechanisms for the increase in phosphorus uptake of waterlogged plants: Soil phosphorus availability, root morphology and uptake kinetics. Oecologia 112:150-155.

Sarkar, R.K., R.N. De, J.N. Reddy, and G. Ramakrishnayya. 1996. Studies on the submergence tolerance mechanism in relation to carbohydrate, chlorophyll and specific leaf weight in rice (Oryza sativa L.). J. Plant Physiol. 149:623-625.

$\mathrm{Su}$, P.H. and C.H. Su. 1996. Metabolic responses of luffa roots to longterm flooding. J. Plant Physiol. 148:735-740.

Tan, S., M. Zhu, and Q. Zhang. 2010. Physiological responses of bermudagrass (Cynodon dactylon) to submergence. Acta Physiol. Plant. 32:133-140.

Vriezen, W.H., Z. Zhou, and D. Van Der Straeten. 2003. Regulation of submergence-induced enhanced shoot elongation in Oryza sativa L. Ann. Bot. 91:263-270.

Wang, K., S. Bian, and Y. Jiang. 2009. Anaerobic metabolism in roots of kentucky bluegrass in response to short-term waterlogging alone and in combination with high temperatures. Plant Soil 314:221-229.

Wang, K. and Y. Jiang. 2007a. Antioxidant responses of creeping bentgrass roots to waterlogging. Crop Sci. 47:232-238.

Wang, K. and Y. Jiang. 2007b. Waterlogging tolerance of kentucky bluegrass cultivars. HortScience 42:386-390.

Waring, E.F. and B.R. Maricle. 2012. Photosynthetic variation and carbon isotope discrimination in invasive wetland grasses in response to flooding. Environ. Expt. Bot. 77:77-86.

Xu, X., H. Wang, X. Qi, Q. Xu, and X. Chen. 2014. Waterlogginginduced increase in fermentation and related gene expression in the root of cucumber (Cucumis sativus L.). Scientia Hort. 179:388395. 
Ye, T., H. Shi, Y. Wang, and Z. Chan. 2015. Contrasting changes caused by drought and submergence stresses in Bermudagrass (Cynodon dactylon). Front. Plant Sci. 6:951, doi: 10.3389/ fpls.2015.00951.

Ye, Y., N.F.Y. Tam, Y.S. Wong, and C.Y. Lu. 2003. Growth and physiological responses of two mangrove species (Bruguiera gymnorrhiza and Kandelia candel) to waterlogging. Environ. Exp. Bot. 49:209-221.

Yin, D., S. Chen, F. Chen, Z. Guan, and W. Fang. 2010. Morphoanatomical and physiological responses of two Dendranthema species to waterlogging. Environ. Exp. Bot. 68:122-130.

Yin, X., C. Zhang, X. Song, and Y. Jiang. 2017. Interactive short-term effects of waterlogging and salinity stress on growth and carbohy- drate, lipid peroxidation, and nutrients in two perennial ryegrass cultivars. J. Amer. Soc. Hort. Sci. 142:110-118.

Zhang, Q., A.J. Zuk, and K. Rue. 2013. Turfgrasses responded differently to salinity, waterlogging, and combined saline-waterlogging conditions. Crop Sci. 53:2686-2692.

Zhou, J., X. Tian, L. Qiao, and P. Qin. 2012. Respiratory enzyme activity and regulation of respiration pathway in seashore mallow (Kosteletzkya virginica) seedlings under waterlogging conditions. Austral. J. Crop Sci. 6:756-762.

Zong, J., Y. Gao, J. Chen, H. Guo, Y. Wang, F. Meng, Y. Jiang, and J. Liu. 2015. Growth and enzymatic activity of four warm-season turfgrass species exposed to waterlogging. J. Amer. Soc. Hort. Sci. 140:151-162. 